Pacific Journal of Mathematics

A NOTE ON STARSHAPED SETS, $(k)$-EXTREME POINTS AND 


\section{A NOTE ON STARSHAPED SETS, ( $k$-EXTREME POINTS AND THE HALF RAY PROPERTY}

\section{N. Stavrakas}

Let $S$ be a compact subset of $R^{d}, d \geqq 2 . \quad S$ is said to have the half-ray property if for each point $x$ of the complement of $S$ there exists a half line with $x$ as vertex having empty intersection with $S$. It is proven that $S$ is starshaped iff $S$ has the half-ray property and the intersection of the stars of the $(d-2)$-extreme points is not empty.

Let $S \subset R^{d}$. We say $x \in S$ is a (k)-extreme point of $S$ provided for every $k+1$ dimensional simplex $D \subset S, x \notin$ relint $D$ where relint $D$ denotes the interior of $D$ relative to the $k+1$ dimensional space $D$ generates. If $y \in S$ the symbol $S(y)$ is defined as $S(y)=\{z \mid z \in S$ and $[y z] \subset S\}$, where $[y z]$ denotes the closed line segment from $y$ to $z$. The symbol $E(S)$ denotes the set of all $(d-2)$-extreme points of $S$. We say $S$ is starshaped if $\operatorname{Ker} S \neq \varnothing$, where $\operatorname{Ker} S=\bigcap_{y \in S} S(y)$. In [1] the following is proved:

THEOREM 1. Let $S \subset R^{d}, d \geqq 2$, be compact and starshaped. Then $\operatorname{Ker} S=\bigcap_{x \in E(S)} S(x)$.

Theorem 1 certainly yields information about the structure of a starshaped set but at the same time raises several questions. First, has Theorem 1 a converse? Specifically, given that $\bigcap_{x \in E(S)} S(x) \neq \varnothing$, under what hypothesis will $S$ be starshaped? Secondly, can the hypothesis of starshaped be replaced with a seemingly more general hypothesis? We answer the latter question in Theorem 2.

Definition 1. Let $S \subset R^{d}$ and let $S^{\sim}$ be the complement of $S$. We say $S$ has the half-ray property if and only if for every $x \in S^{\sim}$ there exists a half line $l$ with $x$ as vertex such that $l \cap S=\varnothing$.

THEOREM 2. Let $S \subset R^{d}, d \geqq 2$, be compact and suppose $\bigcap_{x \in E(S)} S(x) \neq \varnothing$. Then the following are equivalent:

(1) $S$ has the half-ray property.

(2) $\operatorname{Ker} S=\bigcap_{x \in E(S)} S(x)$.

Since for any starshaped set $S, S$ has the half-ray property and $\bigcap_{x \in E(S)} S(x) \neq \varnothing$, the implication $(1) \Rightarrow(2)$ generalizes Theorem 1. Further, the implication $(1) \Rightarrow(2)$ is a type of converse since we assume $\bigcap_{x \in E(S)} S(x)=\varnothing$ and obtain as a conclusion, rather than a hypothesis, that $S$ is starshaped. As a corollary to Theorem 2, 
we obtain a new characterization for starshaped sets.

COROLlaRy 1. Let $S \subset R^{d}, d \geqq 2$, be compact. Then the following are equivalent:

(1) $S$ is starshaped.

(2) $\bigcap_{x \in E(S)} S(x) \neq \varnothing$ and $S$ has the half-ray property.

2. Proof of Theorem 2. In the proof the symbol || || denotes the Euclidean norm and the symbol $\left[a b_{\infty}\right)$ denotes the half line determined by the points $a$ and $b$ with $a$ as vertex.

$(2) \Rightarrow(1)$. This follows immediately since any starshaped set has the half-ray property.

$(1) \Rightarrow(2)$. Let $y \in \bigcap_{x \in E(S)} S(x)$ and we show $y \in \operatorname{Ker} S$. Suppose $y \notin \operatorname{Ker} S$. Then there exists $z \in S$ such that $[y z] \not \subset S$. Let $a \in[y z] \sim S$. Without loss of generality, suppose $a$ is the origin, $O_{v}$. By hypothesis there exists a half line $l=\left[0_{v} b_{\infty}\right)$ with $\left[0_{v} b_{\infty}\right) \cap S=\varnothing$. Let $Q$ be the two dimensional subspace spanned by $y$ and $b$. Now rotate $l$ in $Q$ so that the angle between $l$ and $\left[0_{v} z_{\infty}\right)$ (which is already less than $\pi$ ) decreases. Cease the rotation when $S$ is intersected and let the rotated half line be $l^{*}$. Note $l^{*} \cap S$ is compact and hence $\theta=$ $\sup \left\{\|x\| \mid x \in l^{*} \cap S\right\}$ exists. Let $x \in l^{*} \cap S$ be such that $\|x\|=\theta$. We claim $x \in E(S)$. Suppose not. Then $x \in$ relint $D$ where $D$ is a $d-1$ dimensional simplex in $S$. Since $x \in D \cap Q, \operatorname{dim}(D \cap Q) \geqq 1$. For each $z \in D, z \neq x$ let $\left[z x_{\infty}\right) \cap D$ be $\left[z e_{z}\right]$ and note $x \in\left(z e_{z}\right)$. Let $w \in D \cap Q, w \neq x$. Note $\left[w e_{w}\right] \subset Q$. Now, if $\left[w e_{w}\right] \subset l^{*}$, we contradict the definition of $x$ since $x \in\left(w e_{w}\right)$ and if $\left[w e_{w}\right] \not \subset l^{*}$, we contradict the definition of $l^{*}$. Thus, $x \in E(S)$. Then $[x y] \subset S$ and this contradicts the definition of $l^{*}$. Thus, $y \in \operatorname{Ker} S$ and we are done.

In conclusion, we remark that a triangle in $E^{2}$ is an example of a nonstarshaped set for which $\bigcap_{x \in E(S)} S(x) \neq \varnothing$ and which does not have the half-ray property. The latter shows that in the implication $(1) \Rightarrow(2)$ of Theorem 2 the hypothesis of $S$ having the half-ray property cannot be deleted.

The author wishes to thank the referee for many helpful suggestions.

\section{REFERENCE}

1. J. W. Kenelly, W. R. Hare et. al., Convex components, extreme points, and the convex kernel, Proc. Amer. Math. Soc., 21 (1969), 83-87.

Received November 9, 1973. 


\section{PACIFIC JOURNAL OF MATHEMATICS}

\section{EDITORS}

RICHARD ARENS (Managing Editor)

University of California

Los Angeles, California 90024

\section{J. DUGUNDJI}

Department of Mathematics University of Southern California Los Angeles, California 90007

D. Gilbarg and J. Milgram

Stanford University

Stanford, California 94305

University of Washington
Seattle, Washington 98105

ASSOCIATE EDITORS
E. F, BECKENBACH
B. H. NEUMANN
F. WOLF
K. Yoshida

\section{SUPPORTING INSTITUTIONS}

\author{
UNIVERSITY OF BRITISH COLUMBIA \\ CALIFORNIA INSTITUTE OF TECHNOLOGY \\ UNIVERSITY OF CALIFORNIA \\ MONTANA STATE UNIVERSITY \\ UNIVERSITY OF NEVADA \\ NEW MEXICO STATE UNIVERSITY \\ OREGON STATE UNIVERSITY \\ UNIVERSITY OF OREGON \\ OSAKA UNIVERSITY
}

\author{
UNIVERSITY OF SOUTHERN CALIFORNIA \\ STANFORD UNIVERSITY \\ UNIVERSITY OF TOKYO \\ UNIVERSITY OF UTAH \\ WASHINGTON STATE UNIVERSITY \\ UNIVERSITY OF WASHINGTON \\ * * * * \\ AMERICAN MATHEMATICAL SOCIETY \\ NAVAL WEAPONS CENTER
}

The Supporting Institutions listed above contribute to the cost of publication of this Journal, but they are not owners or publishers and have no responsibility for its content or policies.

Mathematical papers intended for publication in the Pacific Journal of Mathematics should be in typed form or offset-reproduced, (not dittoed), double spaced with large margins. Underline Greek letters in red, German in green, and script in blue. The first paragraph or two must be capable of being used separately as a synopsis of the entire paper. Items of the bibliography should not be cited there unless absolutely necessary, in which case they must be identified by author and Journal, rather than by item number. Manuscripts, in duplicate if possible, may be sent to any one of the four editors. Please classify according to the scheme of Math. Rev. Index to Vol. 39. All other communications to the editors should be addressed to the managing editor, or Elaine Barth, University of California, Los Angeles, California, 90024.

100 reprints are provided free for each article, only if page charges have been substantially paid. Additional copies may be obtained at cost in multiples of 50 .

The Pacific of Journal Mathematics is issued monthly as of January 1966. Regular subscription rate: $\$ 72.00$ a year (6 Vols., 12 issues). Special rate: $\$ 36.00$ a year to individual members of supporting institutions.

Subscriptions, orders for back numbers, and changes of address should be sent to Pacific Journal of Mathematics, 103 Highland Boulevard, Berkeley, California, 94708.

PUBLISHED BY PACIFIC JOURNAL OF MATHEMATICS, A NON-PROFIT CORPORATION

Printed at Kokusai Bunken Insatsusha (International Academic Printing Co., Ltd.), 270, 3-chome Totsuka-cho, Shinjuku-ku, Tokyo 160, Japan.

Copyright (C) 1973 by Pacific Journal of Mathematics Manufactured and first issued in Japan 


\section{Pacific Journal of Mathematics}

\section{Vol. 53, No. $2 \quad$ April, 1974}

Kenneth Abernethy, On characterizing certain classses of first countable spaces by

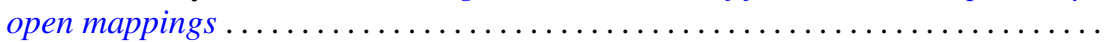

Ross A. Beaumont and Donald Lawver, Strongly semisimple abelian groups .......

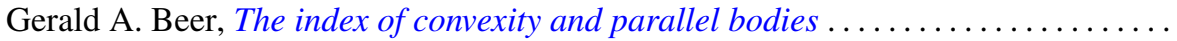

Victor P. Camillo and Kent Ralph Fuller, On Loewy length of rings ..............

Stephen LaVern Campbell, Linear operators for which $T^{*} T$ and $T T^{*}$ commute.

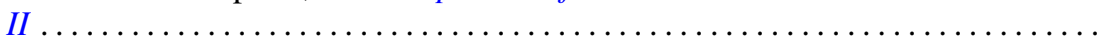

Charles Kam-Tai Chui and Philip Wesley Smith, Characterization of a function by

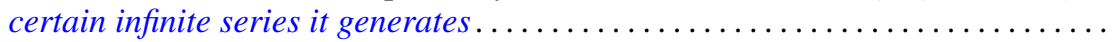

Allan L. Edelson, Conjugations on stably almost complex manifolds . ...........

Patrick John Fleury, Hollow modules and local endomorphism rings . . ..........

Jack Tilden Goodykoontz, Jr., Connectedness im kleinen and local connectedness in

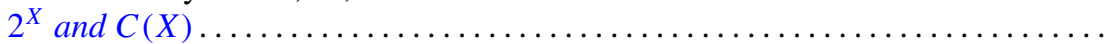

Robert Edward Jamison, II, Functional representation of algebraic intervals .......

Athanassios G. Kartsatos, Nonzero solutions to boundary value problems for

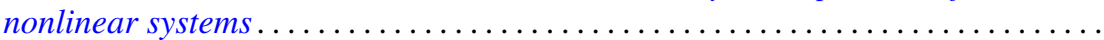

Soon-Kyu Kim, Dennis McGavran and Jingyal Pak, Torus group actions on simply

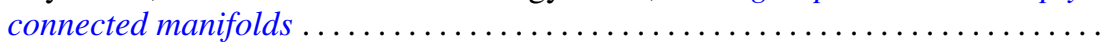

David Anthony Klarner and R. Rado, Arithmetic properties of certain recursively

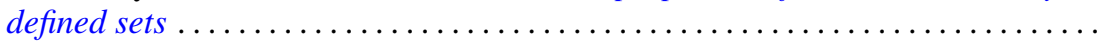

Ray Alden Kunze, On the Frobenius reciprocity theorem for square-integrable

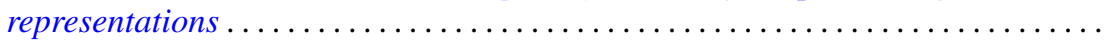

John Lagnese, Existence, uniqueness and limiting behavior of solutions of a class of differential equations in Banach space...

Teck Cheong Lim, A fixed point theorem for families on nonexpansive mappings Lewis Lum, A quasi order characterization of smooth continua

Andy R. Magid, Principal homogeneous spaces and Galois extensions . .

Charles Alan McCarthy, The norm of a certain derivation ..... . .

Louise Elizabeth Moser, On the impossibility of obtaining $S^{2} \times S^{1}$ by elementary surgery along a knot. .

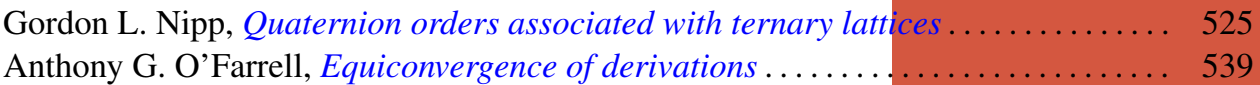

Dorte Olesen, Derivations of $A W^{*}$-algebras are inner . . . . . . . . . . . . . . . 555

Dorte Olesen and Gert Kjærgaard Pedersen, Derivations of $C^{*}$-algebras have

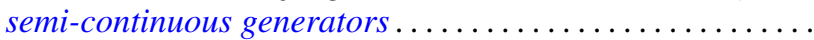

Duane O’Neill, On conjugation cobordism.

Chull Park and S. R. Paranjape, Probabilities of Wiener paths crossing differentiable

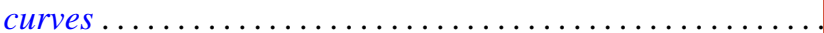

Edward Ralph Rozema, Almost Chebyshev subspaces of $L^{1}(\mu$;

Lesley Millman Sibner and Robert Jules Sibner, A note on the Atiyah-Bott fixed

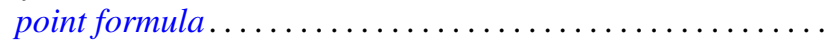

Betty Salzberg Stark, Irreducible subgroups of orthogonal groups generated by

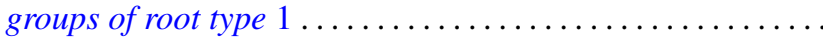

N. Stavrakas, A note on starshaped sets, $(k)$-extreme points and the half ray

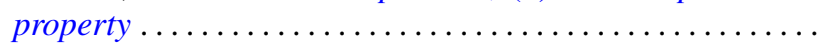

Carl E. Swenson, Direct sum subset decompositions of $Z \ldots \ldots$ 